\title{
Strategic decision making in infrastructure sectors \\ Participatory foresight and strategic planning for sustainable sanitation
}

\section{Eckhard Störmer, Bernhard Truffer, Dübendorf}

\section{Introduction}

Infrastructure sectors in general and utility services in particular, are often considered by economic geographers as rather unexciting exemplars of the «old» regional policy paradigm. Infrastructures are perceived as necessary basic services which have to be provided in a non-discriminatory way to all citizens and firms in a national territory in order to provide good conditions on which further economic and societal development can build. Associated with this «Fordist» goal orientation, a rather narrow and strongly aligned socio-technical regime emerged consisting of physical components with long lifespans and correspondingly «hard wired» institutional structures. As a consequence, infrastructure investment is considered by economic geographers as having lost its legitimacy as a topic of research.

The societal consensus about this development trajectory, however, has been increasingly questioned since the late 1980s: neo-liberal movements, for instance, demanded a stronger orientation towards efficiency goals and promoted deregulation, privatization and liberalization initiatives worldwide. Development agencies questioned the transferability of dominant regime structures to developing countries. New technologies allowed for radically new system configurations concerning the provision of utility services. All of these changes increase pressure on the established regime and call for a broader analysis of potentially more sustainable systems of infrastructure service provision in the future.

The present paper exemplifies the dynamics and challenges faced by the sanitation sector in more detail. Given the long lifespan of most of its technological components, and the splintered organizational structures that are responsible for managing these systems, the sanitation sector is a particularly interesting field of research. In order to better understand how the dominant socio-technical regime is reproduced, the «core» of the sector's decision structures is analyzed in more detail. Particular attention is paid to the procedures established for strategic planning. Given the long lifespans of the material components, the basic layout of the infrastructure system need only be focused on at critical periods of time. For a waste water treatment plant, for example, this critical period would be at the end of its lifespan, i.e. typically after thirty years of operation. At these points, the range of possible future configurations is diverse. Once decisions are taken and implemented, however, the system configuration will be locked-in for about another thirty years. It is argued here that the process of strategic planning today favors the perpetuation of the dominant regime, even though alternatives based on sustainability criteria are available. As an alternative, the authors propose Regional Infrastructure Foresight (RIF) as a decision support tool. By using RIF, uncertainties in context conditions, ranges of options and diverging value positions are explicitly addressed. The method allows for more reflexivity in the decision making process, thereby improving the likelihood of the process to take into account upcoming challenges in these sectors. As a consequence, it is argued that infrastructures might once again become a legitimate topic for research in economic and political geography.

In the following section, the sustainability challenges of sanitation infrastructures in industrialized countries, and in Switzerland in particular, are characterized. This is followed by an introduction to the concept of a socio-technical regime as a means to analyze path dependencies in infrastructures systems. Furthermore, established procedures in strategic planning are analyzed and starting points for developing a more reflexive approach to planning are derived. Section four outlines the «Regional Infrastructure Foresight» method in some detail. Implications from the application of the method, as well as an outlook for future research on infrastructure development in geography are presented in the final section.

\section{The challenges of sanitation}

Sanitation infrastructure has been built up as a general public service in most industrialized countries over the past 50 years. This was a largely undisputed process which guaranteed hygienic living conditions and improved water quality for the population at large. The connection rate in Switzerland grew from below $15 \%$ in 1965 to $97 \%$ in 2005 . The improvement to water quality has to be judged as a huge success in environmental policy implementation. During this build-up phase, a very narrowly aligned socio-technical regime emerged. The material basis of the infrastructure sector consists of concrete sewerages with a 
lifespan of about 80 years and centralized waste water treatment plants with a lifespan of 30 years. These key technological components exhibit strong economies of scale at the level of the individual plant, which leads to a centralizing logic in the system layout (the more water users are connected, the lower the per capita costs). In line with the material requirements of this technology, investment and operation decisions were delegated to public organizations controlled or owned by local communities.

Despite the very obvious success story of the diffusion of this sanitation regime, scholars have recently started to raise doubts about its long-term sustainability (LARSEN \& GUJER 2001; WiLDERER 2004). The main reasons given are that the continuation of the established regime will be challenged by increasing uncertainties in the context conditions under which sanitation will have to operate in the future. Infrastructures are strongly vulnerable to these framework conditions because long-term investments are limited in their flexibility to respond to changes in performance requests (e.g. changes in population and industrial activity, new pollutants, changes in local hydrology). The need to adapt is increasing and changes induced could prove to be excessively costly.

In the 1960 s and 1970s, when this socio-technical regime was developed and implemented nationwide, growth rates of population and industry in the catchment area were considered constant, the emerging technological paradigm remained largely unchallenged and goals by which performance should be assessed were sufficiently clear (elimination of nutrients, un-discriminated access to sanitation service, relative unimportance of costs and tariffs and the provision of these services by public institutions). Over the past decade, however, many of these established certainties have been challenged by new regulatory frameworks (e.g. privatized ownership of utilities), reduced financial stability of communities, risks from new pollutants or contagious diseases, new technologies (e.g. household centered water treatment), regional population and industry dynamics and new hydrological conditions associated with a changing climate. All of these conditions raise doubts as to whether a simple continuation of the socio-technical regime will still be optimal in the mid-term. The example of shrinking regions in Eastern Germany shows the impediments of a too narrow planning approach (Moss 2008): In the early 1990s, significant overcapacities in urban water management infrastructure were planned, based on overly optimistic scenarios of economic development. Today, these lead to pressing operating problems. Rising costs of utility services ultimately impact negatively the attractiveness of the region for new businesses and residents.

\section{The transformation of socio-technical regimes}

In order to understand how socio-technical regimes narrow the potential development paths of a sector and how strategic planning might influence these path dependencies, a closer look is taken here at recent literature in these areas.

\subsection{Infrastructure sectors as socio-technical regimes}

The interaction between material artifacts and social processes has gained considerable interest in the interdisciplinary field of science and technology studies (see Truffer 2008). Several concepts have been developed that emphasize the mutually structuring role between these two spheres which until then were treated as essentially separated and independent. One of the first concepts developed in reference to infrastructure sectors draws attention to Large Technical Systems (LTS) (Hughes 1987, 1998). Strong interdependencies are postulated to exist between technical components, infrastructures, institutions, power relations, organizational practices and patterns of use. This interdependency leads on the one hand to a high degree of malleability of technical structures relative to their social contexts. On the other hand, once established, these socio-technical systems exhibit a high degree of stability and inertia (COUTARD 1999; JoERGES 1988; SummerTon 1994). More recently, the potential for sustainable transformation of socio-technical systems has been analyzed in the literature. This line of thought states that historically, extended periods of dominating matching technical and institutional configurations (so-called socio-technical regimes) may be identified that developed along very narrow trajectories. Fundamental reconfigurations will only take place if major shifts in context conditions (landscape forces) allow new socio-technical configurations (here called niches) to mature and supplant the formerly dominant regimes (see GeEls 2004; GeEls \& SCHOт 2007; RIP \& KEMP 1998).

Applied to the Swiss sanitation sector, the currently dominant regime structures would be the material infrastructures and artifacts in the sanitation system which strongly follow a civil engineering logic. On the whole, the material components consist of concretelined pipes structures in the ground, supplemented by chemical and biological engineering processes for treating the polluted water. Performance conditions are defined by environmental law. Communities are responsible for constructing, operating and partly also controlling the performance of these structures. In line with the material necessities and technological paradigms favored by civil engineers, increasing degrees of centralization were strongly favored. This drive for larger structures is somewhat counterbalanced, however, by the political powers that decide about the 
financing of the projects. The latter are mostly located at community level and consist of lay people, favoring community wide structures that guarantee a larger degree of political control. Caught between these different logics, development trajectories currently observable in urban water management have had a very low degree of variation.

In order to break up these path dependencies, it will not suffice to present some new and promising technological alternatives to the responsible authorities. Rather, a conscious process has to be established which is able to deal with the interrelated nature of the socio-technical regimes in order to identify options for more fundamental reconfigurations. One recent proposal on how such multifaceted transformation policies could be conceived runs under the heading of Transition Management (Rotmans et al. 2001). Here, long-term goal formulation is combined with shorter term experimentation (niche development) for exploring potentially feasible (and more preferable) alternatives (Hoogma et al. 2002). The results of such experiments may be evaluated in the context of participatory visioning exercises (WIEK et al. 2006) and thus generate the context for a long-term reflexive management approach (LOORBACH 2007; Truffer et al. 2008; Voss et al. 2006). However, before a decision procedure conceived along these lines may be proposed, it is necessary to carefully analyze strategic planning processes currently prevailing in the urban water management regime.

\subsection{Conventional planning and transition oriented planning}

Conventional strategic infrastructure planning aims at defining a long-term development corridor for the system as a whole. It should be based on sound predictions of future context conditions and a thorough performance analysis of technical and organizational options (Mugabi et al. 2007). The planning process is usually run by technical experts commissioned by municipal authorities. Currently, solutions are restricted to specific segments, like the waste water treatment plant, and do not refer to the sanitation system as a whole. Suggestions for alternatives are mostly restricted to minor variations of the prevailing configurations. Costs are considered to be the evaluation criterion of overriding importance (see Tab. 1).

This approach is characterized by various limitations which can be analyzed in order to define requirements for more future oriented strategic planning approaches (see Albrechts 2006 regarding strategic spatial planning). Firstly, sound predictions on future developments are often not available for the long-term. In situations of high uncertainties of system interactions and long time scales, foresight approaches (RINGLAND
2002 ) - i.e. the discursive elaboration of possible context developments leading to plausible and coherent scenarios - may be considered to be more appropriate. With regard to environmental decision making, scenario planning has been recently advocated by scholars as a coordination device in interdisciplinary research contexts (DoMINGUEZ et al. 2009; LIENERT et al. 2006; Truffer et al. 2008; WIEK et al. 2006).

Secondly, the search for piecemeal optimizations tends to blind out interdependencies within the system. Strategic planning has to generate an integrated vision for the infrastructure system as a whole. The vision has to consider the entire process chain from the water user to the effluent in order to avoid inconsistent solutions leading to performance bottlenecks. Furthermore, the range of alternative system configurations has to be broadened as far as possible.

Thirdly, the focus on cost efficiency at fixed environmental standards neglects alternative assessment criteria and value positions that have to be considered in order to reach more sustainable solutions. Solutions should be selected respecting the rationality of different sets of values and interests (FLYVBJERG 2001). This implies the involvement of stakeholders and allows reaching a higher degree of reflexivity.

Finally, delegating the definition of the development goal to technical experts clouds the actual «political» responsibilities of local authorities. This kind of delegation still belongs to a kind of trust in experts often found under conditions of «simple modernity». In «late modernity», active trust has to be won by transparent processes involving autonomous, reflexive individuals (GIDDENs 1994). As a consequence, divisions of tasks between decision makers, experts and stakeholders have to be handled explicitly throughout the whole process in order to guarantee legitimacy of the final outcome.

\section{RIF - Participatory Foresight for Infrastructure}

Based on the criticism of conventional planning practice and recent lessons from Transition Management, the Regional Infrastructure Foresight (RIF) methodology has been developed as a strategic planning process at the local/regional level focusing on existing waste water organizations as a starting point. The core elements of a strategic planning process are systematically analyzed with regard to their potential scope of variation (STÖRMER et al. forthcoming).

RIF is conceived as a nine month analysis and assessment process. It is carried out at three levels of participation intensity (see Fig. 1). Firstly, a core team of four 


\begin{tabular}{|c|c|c|}
\hline & $\begin{array}{l}\text { Identification of context conditions and } \\
\text { options } \\
\text { (Factual uncertainties) }\end{array}$ & $\begin{array}{l}\text { Consideration of interests } \\
\text { (Value uncertainties) }\end{array}$ \\
\hline \multicolumn{3}{|c|}{ Conventional approach } \\
\hline Involved actors & $\begin{array}{l}\text { Consultancy engineers and delegates of } \\
\text { technical commission }\end{array}$ & Political representatives \\
\hline $\begin{array}{l}\text { Core aspects } \\
\text { considered }\end{array}$ & $\begin{array}{l}\text { Uncertainties minimized } \\
\text { Options aligned with predominant socio- } \\
\text { technical paradigm }\end{array}$ & $\begin{array}{l}\text { Implicit representation of values } \\
\text { Focus on cost }\end{array}$ \\
\hline Output & $\begin{array}{l}\text { Variant proposal with detailed technical and } \\
\text { financial aspects }\end{array}$ & $\begin{array}{l}\text { Selection of «best» variant depending on } \\
\text { (available) cost and (implicit, current) interest } \\
\text { positions }\end{array}$ \\
\hline Decision mode & $\begin{array}{l}\text { Technical-expertocratic, based on technolo- } \\
\text { gical know-how exclusively } \\
\text { Time reference short to medium term }\end{array}$ & $\begin{array}{l}\text { Political-expertocratic, based on formalized } \\
\text { party representations in technical commissions }\end{array}$ \\
\hline \multicolumn{3}{|c|}{ Transition oriented approach } \\
\hline Involved actors & Core team & Systematically sampled stakeholders \\
\hline $\begin{array}{l}\text { Core aspects } \\
\text { considered }\end{array}$ & $\begin{array}{l}\text { Systematic analysis of context uncertainties } \\
\text { Elaboration of conceivable option ranges }\end{array}$ & $\begin{array}{l}\text { Consideration of systematic value tree } \\
\text { Evaluations based on future interest positions } \\
\text { Comparison with «balanced» goal weights }\end{array}$ \\
\hline Output & $\begin{array}{l}\text { Context scenarios } \\
\text { Generic options } \\
\text { Specification of uncertainties }\end{array}$ & $\begin{array}{l}\text { Ranking of generic options relative to context } \\
\text { and value uncertainties } \\
\text { Identification of sustainability deficits } \\
\text { Specification of feasibility studies and } \\
\text { technological variant assessment }\end{array}$ \\
\hline Decision mode & $\begin{array}{l}\text { Creative - competence based } \\
\text { Time reference medium to long term }\end{array}$ & $\begin{array}{l}\text { Representative of interest positions in } \\
\text { participatory stakeholder workshops }\end{array}$ \\
\hline
\end{tabular}

Tab. 1: Conventional versus transition oriented planning Konventionelle und transitionsorientierte Planung im Vergleich Planification conventionnelle par rapport à une planification orientée vers la transition

to seven decision makers participates in the whole planning process consisting of about seven half day working sessions. Further, eight to sixteen stakeholder representatives are involved in two one-day workshops that aim at creating regional development scenarios and at assessing system alternatives. The actual local decision making body reflects on these results and decides upon the implications for the future planning process. In the development phase, three to five researchers - including the two authors - take the role of process facilitators who organize, structure and moderate the planning process.

The RIF method is structured as follows (described in detail in STÖRMER et al. 2008):

(i) Uncertainties concerning changing context conditions are analyzed for a time horizon of about 25 years. In the first stakeholder workshop, three to four scenarios of regional and policy development are con- structed. A typical set of scenarios might look like the following: (a) income-strong region with high quality life style, (b) economically booming region with low willingness to pay for environmental services, and (c) shrinking region with a low ability to pay for environmental services.

(ii) The range of alternative system configurations is open to include the full range of conceivable organizational and technical alternatives. In particular, conventional system boundaries (or established regime delimitations) are questioned both with regard to their thematic boundaries (sanitation, integrated water services, multi utility) and their spatial delimitations (e.g. address catchment level processes). The options' advantages and risks are assessed in light of the context conditions defined by the scenarios. The core team develops three to four technical and organizational alternatives for the entire sanitation system: (a) The option «core competence» asks the existing 


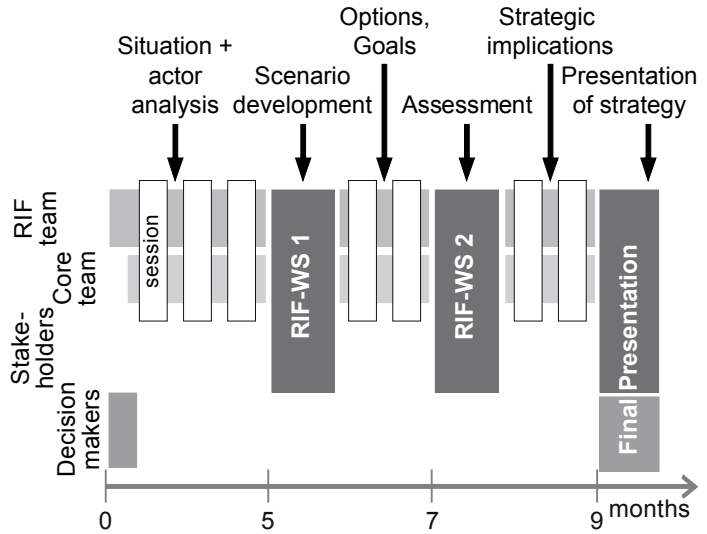

Fig. 1: Regional Infrastructure Foresight process Der Prozess des «Regional Infrastructure Foresight» Processus prospectif du «Regional Infrastructure Foresight»

Graphics: Y. LEHNHARD

sanitation organizations to fulfill their tasks by optimizing their internal structures and outsourcing those processes that create specific problems; (b) «Multi utility» describes an organizational structure that aims at integrating all sanitation related tasks within a region (potentially expanding their business into the provision of other utility services); (c) The option «technical or organizational merger» increases professionalism by expanding the geographical range of the organization; (d) «Decentralization» describes a system configuration which builds strongly on on-site waste water treatment technologies, due to rising costs as a consequence of postponed sewer maintenance.

(iii) The whole bundle of sustainability goals is taken into account to assess the sanitation system alternatives systematically. The goals considered should be as encompassing as possible. This may be achieved by relying on a decision analysis tool like a value tree of sustainable infrastructure goals (for an adaptation on water issues of the Swiss MONET sustainability criteria catalogue, see Bundesamt Für STATISTIK (BFS) et al. 2003). By integrating the scenarios, options and goals, the core team identifies the pros and cons of each option in the context of each scenario by trying to apply a balanced weighting of the different sustainability goals.

(iv) By involving a broad range of stakeholder perspectives, it is possible to consider a wider range of knowledge stocks and value positions. In the second workshop, the stakeholders carry out the same assess- ments of the options as the core team but take into account specific weightings of the goal tree that correspond to specific interest positions. Thereby, possible conflict lines and corresponding preferences may be identified.

(v) This overall assessment is synthesized by the core team in a strategy report that defines a long-term vision of the future sanitation system, a list of critical context conditions that are decisive for its future sustainability and a plan for intermediary steps to reach this longterm goal. The strategy report serves as a guideline on which future technical and organizational decisions can be based. The strategy report is presented to the official decision making bodies and the participants of the workshops for implementation.

After developing the conceptual framework of the method, the research team issued a call for participation on the RIF pilot study. The selection of the candidates was based on a typology of the Swiss sanitation system (MAURer \& Herlyn 2006) and reflects differences with regard to the centrality of the region, current position in the lifespan of the sanitation infrastructure and different forms and sizes of organization. The selection process resulted in the choice of the following three locations: Klettgau (predominantly rural), Kiesental (periurban area), and Dübendorf (suburban agglomeration). The case studies were carried out from the end of 2006 to early 2008.

\section{Strategic decision making in infrastructure and regional development}

Based on the lessons learned from the case studies in Switzerland, conclusions can be drawn about the possible merits of this kind of approach for decision making in spatial contexts.

One central element of the RIF process is the systematic consideration of future social and economic conditions in the region driven by external «landscape» factors like globalization and climate change, as well as internal regional development capacities. During this step, awareness of uncertainties is raised and a «thinking ahead» concerning unforeseen developments is promoted. The consideration of the whole range of sustainability criteria allows systematic analysis of impacts of different system configurations for the provision of public services. The study of a broad set of value positions allows generation of an awareness of different communities' and stakeholders' interests in regional policy making. Furthermore, an improvement in the range of alternatives for sanitation system configurations helps to overcome the path-reinforcing logic of conventional planning. 
In the Klettgau pilot case, for example, a conventional planning process preceded the application of the RIF method. It produced a recommendation to incrementally refurbish the prevailing waste water treatment plant. Both the technological configurations as well as the organizational and governance structure were largely left unchanged. The RIF process, in contrast, led to a radically different solution, namely the decommissioning of the local waste water plant and an organizational merger with an institution across the border in Germany, a solution that had not seriously been taken into account before.

One of the core strengths of RIF lies in its inclusion of the dynamic interaction between regional conditions and infrastructure challenges. The stipulation to investigate the regional status of appropriate infrastructures as well as the reverse effect of infrastructure performance on the regional development potential consequently leads to infrastructure no longer being seen solely as a powerful enabler for regional development. Rather, limitations in future infrastructures - e.g. too large, too small, too expensive, expansion too slow - can be taken better into account.

Several expansions of the RIF method suggest further research and development needs:

(i) While RIF is developed and tested for strategy development of one or some community-based organizations, regional water management agencies could use a similar strategic tool to develop coordinated water protection strategies. Multi-level infrastructure planning could ensure catchment wide development plans with corresponding actions at the regional level. Furthermore, a federal or national Infrastructure Foresight would deliver a guideline for federal and national infrastructure policy initiatives as a continuous strategy tool.

(ii) Furthermore, regional infrastructure planning has to be embedded in broader reflections of regional development. However, today's regional policy is mostly focused on improving regional competitiveness by emphasizing growth strategies of business sectors and their regional networks (see, for instance, regional foresight initiatives in KOSCHATZKY 2005 or GERTLER \& WoLfe 2004). In contrast, the RIF approach allows an opening up of the «black box» of material and institutional background generally taken for granted, an aspect which only becomes evident when the services are lacking or failing (AMIN 2006). The application domain of the RIF method should, thus, be expanded to other public services that lie in the responsibility of communities, like water supply, waste management, public schools, child care, healthcare or others. If, as is claimed here, context conditions and strategic alterna- tives become more uncertain, participative, reflexive approaches to planning will ultimately have a strong bearing in the definition of general regional development strategies. As may be seen in the example above, even a mundane activity, such as sanitation planning, forces citizens to actively reflect on their municipalities' futures in the context of wider regional development. In this sense, regional infrastructure foresight may become an important area for regional learning and communication, with particular relevance for the everyday lives of citizens and, thus, may offer a starting point on which more encompassing foresight exercises could build.

This paper briefly presented basic arguments for an interaction of strategic planning for sustainable infrastructures with regional planning. It thereby elevates the topic of infrastructure from an «unexciting» basic service to a core element of future oriented regional development strategy. It is time for geography to rediscover infrastructures as a legitimate topic of research.

\section{Acknowledgements}

The authors would like to thank the Swiss National Science Foundation for funding the project «Regional Infrastructure Foresight» within the National Research Programme 54 «Sustainable Development of the Built Environment».

\section{References}

Albrechts, L. (2006): Shifts in strategic spatial planning? Some evidence from Europe and Australia. - In: Environment and Planning A, 38: 1149-1170.

Amin, A. (2006): The good city. - In: Urban Studies 43: 1009-1023.

BUNdESAMT FÜR STATISTIK (BFS), BUndesamt FÜR UMWELt, WaLd Und LANDSChaft (BUWAL), BundesAMT FÜR RAUMENTWICKLUNG (ARE) (Hrsg.) (2003): Nachhaltige Entwicklung in der Schweiz. Indikatoren und Kommentare. - Neuchâtel: Office fédéral de la statistique (OFS).

Coutard, O. (1999): The governance of large technical systems. - London: Routledge.

Dominguez, D., Worch, H., Truffer, B., Markard, J. \& W. GUJER (2009): Closing the capability gap: strategic planning for the infrastructure sector. - In: California Management Review 51, 2: 30-50.

FlyvBJERG, B. (2001): Making social science matter: why social inquiry fails and how it can succeed again. - Cambridge: Cambridge University Press.

GeELs, F.W. (2004): From sectoral systems of innovation to socio-technical systems: insights about dynamics and change from sociology and institutional theory. - In: Research Policy 33, 6/7: 897-920. 
GeELs, F.W. \& J. Schot (2007): Typology of sociotechnical transition pathways. - In: Research Policy 36: 399-417.

Gertler, M.S. \& D.A. Wolfe (2004): Local social knowledge management: community actors, institutions and multilevel governance in regional foresight exercises. - In: Futures 36: 45-65.

GIDDENS A. (1994): Living in a post-traditional society. - In: Beck, U., Giddens, A. \& S. Lash (eds): Reflexive modernization: politics, tradition and aesthetics in the modern social order. - Cambridge: Polity Press: 56-109. Hoogma, R., Kemp, R., Schot, J. \& B. Truffer (2002): Experimenting for sustainable transport. The approach of strategic niche management. - London: Spon.

Hughes, T.P. (1987): The evolution of large technical systems. - In: Bijker, W.E., Hughes, T.P. \& T. Pinch (eds): The social construction of technological systems. - Cambridge, Massachusetts: The MIT Press: 51-82.

Hughes, T.P. (1998): Rescuing Prometheus: four monumental projects that changed the modern world. - New York: Pantheon Books.

JoERGES, B. (1988): Large technical systems: concepts and issues. - In: MAYnTz, R. \& T. Hughes (eds): The development of large technical systems. - Frankfurt am Main: Campus Verlag, Boulder, Colorado: Westview Press: 9-36.

KoschatzKy, K (2005): Foresight as a governance concept at the interface between global challenges and regional innovation potentials. - In: European Planning Studies 13, 4: 619-639.

LARSEN, T.A. \& W. GuJer (2001): Waste design and source control lead to flexibility in wastewater management. - In: Water Science and Technology 43, 5: 309-318.

Lienert, J., Monstadt, J. \& B. Truffer (2006): Future scenarios for a sustainable water sector: a case study from Switzerland. - In: Environmental Science and Technology 40, 2: 436-442.

LoorBACH, D. (2007): Transition management: a new mode of governance for sustainable development. - Utrecht: International Books.

MaUrer, M. \& A. Herlyn (2006): Zustand, Kosten und Investitionsbedarf der schweizerischen Abwasserentsorgung. - Dübendorf $(\mathrm{CH})$ : Eawag.

Moss, T. (2008): «Cold spots» of urban infrastructure: «shrinking» processes in Eastern Germany and the modern infrastructural ideal. - In: International Journal of Urban and Regional Research 32, 2: 436-451.

Mugabi, J., Kayaga, S. \& C. NuIRU (2007): Strategic planning for water utilities in developing countries. - In: Utilities Policy 15, 1:1-8.

RINGLAND, G. (2002): Scenario planning: managing for the future. - Chichester: John Wiley \& Sons.

RIP, A. \& R. Kemp (1998): Technological change. - In: RAYNeR, S. \& E. MALone (eds): Human choice and climate change: resources and technology. - Columbus, Ohio: Battelle Press: 327-399.
Rotmans, J., Kemp, R. \& M. van Asselt (2001): More evolution than revolution: transition management in public policy. - In: Foresight 3, 1:15-31.

Störmer, E., Truffer, B., Ruef, A., Dominguez, D., Maurer, M., Klinke, A., Herlyn, A. \& J. Markard (2008): Nachhaltige Strategieentwicklung für die regionale Abwasserwirtschaft. Handbuch zur Methode «Regional Infrastructure Foresight». - Dübendorf: Selbstverlag der Eawag (Swiss Federal Institute of Aquatic Science and Technology).

Störmer, E., Truffer, B., Dominguez, D., Gujer, W., Herlyn, A., Hiessl, H., Kastenholz, H., Klinke, A., Markard, J., Maurer, M. \& A. Ruef (forthcoming): The exploratory analysis of trade-offs in strategic planning. Lessons from Regional Infrastructure Foresight. - In: Technological Forecasting and Social Change.

Summerton, J. (ed.) (1994): Changing large technical systems. - Boulder, Colorado, Oxford: Westview Press. Truffer, B. (2008): Society, technology and region. Contributions from the social study of technology to economic geography. - In: Environment and Planning A 40, 4: 966-985.

Truffer, B., Voss, J.-P. \& K. Konrad (2008): Mapping expectations for system transformations: lessons from sustainability foresight in German utility sectors. - In: Technological Forecasting and Social Change 75, 9: 1360-1372.

Voss, J.-P., Truffer, B. \& K. Konrad (2006): Sustainability foresight. Reflexive governance for the transformation of the utility system. - In: Voss, J.-P., Kemp, R. $\&$ D. BAUKNECHT (eds): Reflexive governance for sustainable development. - Cheltenham: Edward Elgar: 272-315.

WieK, A., Binder, C. R. \& R.W. Scholz (2006): Functions of scenarios in transition processes. - Futures 38: 740-766.

WILDERER, P.A. (2004): Some thoughts about future perspectives of water and wastewater management. - In: Water Science and Technology 49, 5/6:35-37.

\section{Abstract: Strategic decision making in infrastructure sectors. Participatory foresight and strategic planning for sustainable sanitation}

Infrastructure sectors in general, and urban water management in particular, have developed over the past couple of decades within the confines of a rather narrow and stable socio-technical regime. Nowadays, these infrastructures are increasingly confronted with uncertain context conditions, a broadened spectrum of technological alternatives and an increasing heterogeneity of value positions. As a consequence, the longterm sustainability of these sectors has been questioned by many commentators. Of particular importance is the way strategic decisions are made. Current approaches tend to block important opportunities for sustainable transformation. It is argued here that a more reflex- 
ive, discursive and participative approach to strategic planning is needed. The paper introduces «Regional Infrastructure Foresight» (RIF) as a method which combines foresight on regional framework conditions with a stakeholder assessment of a broad range of system options. The paper presents the methodology in some detail and discusses the main lessons learned through three empirical applications in the Swiss sanitation sector. Based on these experiences, it is argued that strategic decision making in infrastructures is of high relevance for regional policy and therefore warrants more attention in future research in economic and political geography.

Keywords: infrastructure, sanitation, transition management, strategic planning, foresight

\section{Zusammenfassung: Strategische Entscheidungs- findung in Infrastruktursektoren. Partizipative Vorausschau und strategische Planung nachhaltiger Abwasserwirtschaft}

Infrastrukturen im Allgemeinen und die Siedlungswasserwirtschaft im Besonderen haben sich über die letzten Jahrzehnte innerhalb eines eng begrenzten, stabilen sozio-technischen Regimes entwickelt. Heute sind diese Infrastrukturen jedoch gekennzeichnet durch zunehmend unsichere Rahmenbedingungen, ein breiteres Spektrum an technischen Alternativen und deutlich heterogenere Werthaltungen. Daher wird die langfristige Nachhaltigkeit dieser Sektoren von Vielen hinterfragt. Besonders wichtig ist die Art der Entscheidungsfindung. Die vorherrschenden Methoden neigen dazu, bedeutende Möglichkeiten einer nachhaltigen Transformation der Infrastrukturen auszublenden. Der vorliegende Artikel argumentiert, dass ein stärker reflexiver, diskursiver und partizipativer Ansatz in der strategischen Planung notwendig ist. Die Methode «Regional Infrastructure Foresight» wird eingeführt, die Vorausschau der regionalen Rahmenbedingungen, verknüpft mit einer Stakeholder-Bewertung eines breiten Spektrums von Systemoptionen. Der Artikel führt in die Methode ein und diskutiert die Kernergebnisse aus drei Pilotprozessen der Schweizer Siedlungswasserwirtschaft. Basierend auf diesen Erkenntnissen argumentieren die Autoren, dass strategische Entscheidungsfindung für Infrastrukturen ein hoch relevantes Feld für die Regionalpolitik darstellt, woraus sich vielfältiger, zukünftiger Forschungsbedarf für die Wirtschafts- und Politische Geographie ableiten lässt.

Schlüsselwörter: Infrastruktur, Abwasserwirtschaft, Transition Management, strategische Planung, Zukunftsvorausschau
Résumé: Prise de décision stratégique dans le secteur des infrastructures. Une approche prospective participative pour la planification stratégique d'un assainissement durable

Au cours des dernières décennies, le secteur des infrastructures en général et celui de l'assainissement urbain en particulier ont évolué dans un régime stable et plutôt étroit. Aujourd'hui, ces secteurs sont de plus en plus confrontés aux incertitudes de l'évolution du contexte général, à l'accroissement des alternatives techniques disponibles et à l'hétérogénéité grandissante des positionnements de valeur. Leur durabilité est par conséquent remise en question par de nombreux critiques. Mais c'est surtout la manière dont les décisions stratégiques sont prises qui est capitale. Les approches courantes ont tendance à ignorer les opportunités permettant une transformation durable des infrastructures. Cet article met en évidence l'importance d'une approche plus réflexive, discursive et participative dans la planification stratégique des infrastructures. Il introduit la méthode dite du «Regional Infrastructure Foresight» (RIF) qui combine une approche prospective du contexte régional avec l'évaluation par les acteurs d'une large gamme de solutions systémiques. Après une présentation détaillée de la méthode, l'article discute des principaux enseignements tirés de trois applications pilotes dans le secteur de l'assainissement en Suisse. Ces expériences montrent l'utilité, pour la politique régionale, d'une démarche stratégique liée à la prise de décision dans le secteur des infrastructures. Elles appellent à approfondir la recherche en géographie économique et politique sur ce thème.

Mots-clés: infrastructure, épuration des eaux usées, gestion de transitions, planification stratégique, prospective

Dr. Eckhard Störmer, PD Dr. Bernhard Truffer, Eawag, Swiss Federal Institute of Aquatic Science and Technology, Cirus, Innovation Research in Utility Sectors, Überlandstrasse 133, P.O. Box 611, CH-8600 Dübendorf, Switzerland.

e-mail:

eckhard.stoermer@eawag.ch

bernhard.truffer@eawag.ch

Manuskripteingang/received/manuscrit entré le 17.9.2008

Annahme zum Druck/accepted for publication/accepté pour l'impression: 17.5.2009 